\title{
Effect of Carbon Partitioning, Carbide Precipitation, and Grain Size on Brittle Fracture of Ultra-High-Strength, Low-Carbon Steel after Welding by a Quenching and Partitioning Process
}

\author{
Farnoosh Forouzan ${ }^{1,2, *}$, M. Agustina Guitar ${ }^{2}$, Esa Vuorinen ${ }^{1}$ and Frank Mücklich ${ }^{2}$ \\ 1 Department of Engineering Sciences and Mathematics, Luleå University of Technology, SE-97187 Luleå, \\ Sweden; esa.vuorinen@ltu.se \\ 2 Department of Materials Science, Functional Materials, Saarland University, D-66041 Saarbrücken, Germany; \\ a.guitar@mx.uni-saarland.de (M.A.G.), muecke@matsci.uni-sb.de (F.M.) \\ * Correspondence: farnoosh.forouzan@ltu.se; Tel.: +46-920-493-217
}

Received: 16 August 2018; Accepted: 18 September 2018; Published: 23 September 2018

\begin{abstract}
To improve the weld zone properties of Advanced High Strength Steel (AHSS), quenching and partitioning $(\mathrm{Q} \& \mathrm{P})$ has been used immediately after laser welding of a low-carbon steel. However, the mechanical properties can be affected for several reasons: (i) The carbon content and amount of retained austenite, bainite, and fresh martensite; (ii) Precipitate size and distribution; (iii) Grain size. In this work, carbon movements during the partitioning stage and prediction of $\mathrm{Ti}(\mathrm{C}, \mathrm{N})$, and $\mathrm{MoC}$ precipitation at different partitioning temperatures have been simulated by using Thermocalc, Dictra, and TC-PRISMA. Verification and comparison of the experimental results were performed by optical microscopy, X-ray diffraction (XRD), Scanning Electron Microscop (SEM), and Scanning Transmission Electron Microscopy (STEM), and Energy Dispersive Spectroscopy (EDS) and Electron Backscatter Scanning Diffraction (EBSD) analysis were used to investigate the effect of martensitic/bainitic packet size. Results show that the increase in the number density of small precipitates in the sample partitioned at $640{ }^{\circ} \mathrm{C}$ compensates for the increase in crystallographic packets size. The strength and ductility values are kept at a high level, but the impact toughness will decrease considerably.
\end{abstract}

Keywords: low-carbon AHSS; Q\&P; toughness; modelling; precipitation; martensite packet

\section{Introduction}

The automotive industry focuses on increasing the use of advanced high-strength steels (AHSS) in order to satisfy the current demand for decreasing the fuel consumption by reduced weight and increasing vehicle safety by using these steels in different energy-absorbing components [1]. Usually, these AHSS are produced by thermomechanical processes, which control the microstructure and grain size as well as the precipitation hardening of micro-alloyed steels.

During welding of AHSS, the weld area will be completely changed and the excellent properties (i.e., tensile strength, toughness) will be lost. This means that the welded area could be the best area for crack propagation [2]. Therefore, pre-and/or post-welding treatment is necessary to improve the properties of this zone. Laser welding is a popular method in the industry because it is fast, creates narrow and deep welds, and can be used for different materials and shapes. So, in this work, a quenching and partitioning [3] method has been applied for post-welding treatment in order to control the microstructure [4]. The final structure will contain tempered martensite (which increases the yield strength) with retained austenite (which improves the ductility), and, depending on the 
Q\&P conditions and chemical composition of the steel, some bainite and fresh martensite can also be formed [3-5].

However, carbide/nitride precipitation during the partitioning step cannot be avoided, even in low-carbon [6] or in high-carbon, high-silicon steels [7]. Therefore, one of the critical aspects is to monitor the behavior of precipitates during the process. Although precipitates and/or particles are designed to strengthen the material by a precipitation hardening mechanism, they could act as cleavage initiation sites and deteriorate the toughness [8-10]. Fairchild et al. [11] showed that a strong inclusion-matrix bond is why TiN inclusions are potent cleavage initiators in steels even with modest Ti contents. Another study by Di Schino et al. [12] on the effect of $\mathrm{Nb}$ microalloying on the heat-affected zone (HAZ) showed that a small difference in $\mathrm{Nb}$ content is able to influence the size of the bainitic packet, which results in both toughness and hardness.

Several works have been done on the mechanism of Q\&P up to now [4,13-17], while only a few papers have investigated the fracture mechanisms and toughness of Q\&P steels $[18,19]$. Fracture causes could mainly be related to: (i) Kinetics of carbon partitioning and stabilization of retained austenite (RA) in the structure, because it has been shown that increasing volume fraction of RA due to the TRIP effect delays the crack propagation [20]; (ii) Kinetics, size, number density and shape of secondary precipitates; and (iii) Microstructural refinement can be very effective for improving the toughness. Wang et al. [21] found that, when the cleavage crack encounters another packet of martensite, it may be arrested and then largely changes its propagation direction.

Previous studies by the authors [4,22] on the effect of Q\&P after laser welding of a low-carbon steel showed that samples partitioned at a higher temperature had the best tensile properties but very low Charpy V impact toughness results. In the present work, in order to investigate the origins of such contradictory results, the abovementioned main issues are studied. Carbon diffusion from $\alpha^{\prime}$ to retained austenite was modeled by a diffusion-controlled transformation tool (DICTRA) [23] during quenching and partitioning. The type, size, and distribution of the precipitates were evaluated using a scanning transmission electron microscope (STEM) in order to verify the precipitation prediction modeling by TC-PRISMA. Finally, the effect of the packet size of martensite/bainite laths on crack propagation has been investigated by electron backscatter diffraction (EBSD).

\section{Materials and Methods}

Laser welding was conducted on $5.5 \mathrm{~mm}$ thick sheets of 'Domex 960' advanced high strength steel from SSAB (Stockholm, Sweden). This steel is thermomechanically processed (TMP) and was received in TMP condition with a yield strength of $960 \mathrm{MPa}$ and elongation (A5) of approximately $8 \%$. The chemical composition of the steel is given in Table 1, but for Thermocalc simulations, a simplified composition of Fe-0.08 wt \% C $-1.78 \mathrm{wt} \% \mathrm{Mn}-0.5 \mathrm{wt} \% \mathrm{Mo}-0.187 \mathrm{wt} \% \mathrm{Ti}-0.004 \mathrm{wt} \% \mathrm{~N}$ is assumed. All calculations were carried out with the thermodynamic database TCFE8 [24] and mobility database of MOBFE3 [25].

Table 1. The chemical composition of the steel used in the experiments (wt \%).

\begin{tabular}{cccccccccccccc}
\hline $\mathbf{C}$ & $\mathbf{S i}$ & $\mathbf{M n}$ & $\mathbf{P}$ & $\mathbf{S}$ & $\mathbf{A l}$ & $\mathbf{T i}$ & $\mathbf{M o}$ & $\mathbf{C r}$ & $\mathbf{N i}$ & $\mathbf{C u}$ & $\mathbf{V}$ & $\mathbf{N}$ & $\mathbf{F e}$ \\
\hline 0.082 & 0.23 & 1.79 & 0.008 & 0.001 & 0.038 & 0.184 & 0.503 & 0.064 & 0.296 & 0.016 & 0.012 & 0.004 & Balance \\
\hline
\end{tabular}

For the welding, process the keyhole penetration mode, with ytterbium Fiber Laser (YLR Laser-15000, IPG Photonics, Oxford, MA, USA), $5 \mathrm{~kW}$ power, travel speed of $1.1 \mathrm{~m} / \mathrm{min}$, and Argon shielding gas with a flow rate of $20 \mathrm{~L} / \mathrm{min}$, was used. The welded specimens were subjected to post heat treatment immediately after the laser welding. For that, an induction heater was placed above the specimen. The temperature was monitored during the whole procedure of welding and Q\&P, by using welded thermocouples located $1.5 \mathrm{~mm}$ from the fusion zone (FZ). For the same quenching temperature (QT) of $355^{\circ} \mathrm{C}$ (approx. equal to $60 \%$ initial martensite), three partitioning temperatures (PT) of $440{ }^{\circ} \mathrm{C}$ 
$\left(20{ }^{\circ} \mathrm{C}\right.$ above $\left.\mathrm{M}_{\mathrm{s}}\right), 540{ }^{\circ} \mathrm{C}$ (half between $\mathrm{M}_{\mathrm{s}}$ and $\left.\mathrm{B}_{\mathrm{s}}\right)$, and $640{ }^{\circ} \mathrm{C}\left(\mathrm{B}_{\mathrm{s}}\right)$ and three partitioning times $(\mathrm{Pt})$ were tested.

Tensile testing was performed on cross weld specimens; the tensile axis was kept perpendicular to the rolling direction of the steel sheet, while the weld zone is located exactly in the middle of the dog-bone-shaped A50 samples. Charpy V notch samples were prepared according to the standard EN ISO 6892-1:2009 and testing was conducted on transverse specimens with a notch in the center of FZ. Results showed that all the samples that were partitioned at $640^{\circ} \mathrm{C}$ had very low impact toughness.

In order to investigate the reasons, the samples that showed the best and the worst toughness were selected for comparison, see Table 2.

Table 2. Mechanical properties of samples Q\&P treated immediately after laser welding. (Energy = Absorbed energy during Charpy $\mathrm{V}$ test at $20^{\circ} \mathrm{C}$.)

\begin{tabular}{ccccccccc}
\hline Sample Code & $\mathbf{Q T}\left({ }^{\circ} \mathbf{C}\right)$ & $\mathbf{P T}\left({ }^{\circ} \mathbf{C}\right)$ & $\mathbf{P t}(\mathbf{s})$ & $\mathbf{A}_{\mathbf{8 0}}(\%)$ & $\mathbf{A}_{\mathbf{5}}(\%)$ & $\mathbf{R p}_{\mathbf{0 . 2}}(\mathbf{M P a})$ & $\left.\mathbf{R}_{\mathrm{m}} \mathbf{( M P a}\right)$ & Energy $\left(\mathbf{J} / \mathrm{cm}^{2}\right)$ \\
\hline $\mathrm{S}(540,5)$ & 355 & 540 & 5 & 4 & 6 & 1005 & 1025 & 109 \\
$\mathrm{~S}(640,50)$ & 355 & 640 & 50 & 6 & 8 & 1034 & 1051 & 4 \\
\hline
\end{tabular}

The precipitate characterization was determined from C-replicas taken from weld area (FZ and HAZ) with a FE-SEM Helios Nanolab 600 (FEI, Hillsboro, OR, USA) working with an acceleration voltage of $30 \mathrm{kV}$ and a $1.4 \mathrm{nA}$ beam current. The precipitate sizes were determined by image analysis (I-A) of STEM micrographs using the software A4i@ (Aquinto AG, Berlin, Germany). The carbide chemistry was identified in transmission using energy-dispersive X-rays (EDX) (Jeol Ltd., Tokyo, Japan) at $30 \mathrm{kV}$ accelerating voltage. Electron Backscatter Diffraction (EBSD) was carried out on HAZ using an accelerating voltage of $20 \mathrm{kV}$, a beam current of $11 \mathrm{nA}$, and a step size of $150 \mathrm{~nm}$ and $100 \mathrm{~nm}$ for Q\&P and base metal (BM) samples, respectively. The raw data were filtered by confidence index (CI) of $\mathrm{CI}>0.09$ after a $\mathrm{CI}$ cleanup and grain dilation (grain tolerance angle $5^{\circ}$ and minimum grain size 2). The grains were defined as at least two adjacent points with similar orientation within a range of $15^{\circ}$ misorientation.

\section{Results and Discussion}

\subsection{Fracture Results}

Figure 1 shows dimple and cleavage mix-mode fracture in all fractographies, but the average radius of dimples in $S(540,5)$ (Figure 1a) is smaller than the other samples including the reference weld without any heat treatment (Figure 1c), and S(640,50) (Figure 1b).
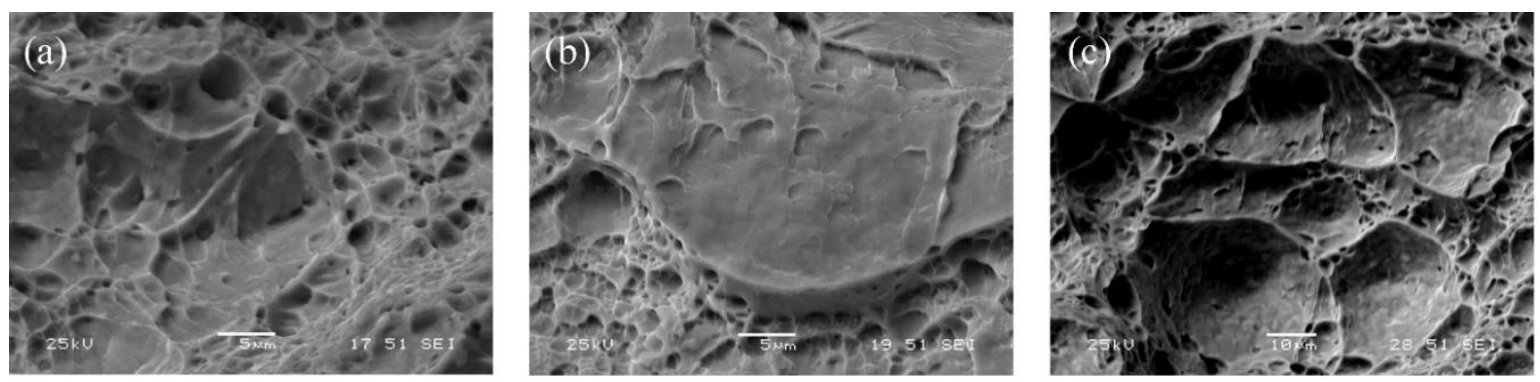

Figure 1. Fracture surface after tensile test of following samples; (a) $S(540,5)$, shows ductile fracture of HAZ (b) $S(640,50)$, shows brittle fracture of HAZ and (c) reference weld.

\subsection{Thermodynamic Modeling}

In order to understand the critical temperatures of phase transformation and formation of stable precipitates in an equilibrium condition of Domex 960, the amount of phases at different temperatures was calculated with Thermocalc [23]. Although the temperatures and amount of phases could be far 
from the real conditions during Q\&P, this calculation could give a good overview of the most stable microconstituents. Figure 2 shows that $\mathrm{Ti}(\mathrm{C}, \mathrm{N})$ has the highest tendency to form the first carbonitrides in this system. It will start when there is still some liquid in the system and the precipitation will continue until it reaches room temperature. After that, two other carbides $\left(\mathrm{M}_{7} \mathrm{C}_{3}\right)$ and cementite will nucleate around $700{ }^{\circ} \mathrm{C}$, but they are not stable and will disappear very soon around $600{ }^{\circ} \mathrm{C}$, while their amount is also very small (e.g., $0.001 \mathrm{~mol}$ ). The next important precipitate in this system in the critical temperature range of $440{ }^{\circ} \mathrm{C}$ to $640{ }^{\circ} \mathrm{C}$, is $\mathrm{MoC}$, as expected from its enthalpy for carbide formation in comparison with other alloying elements in this steel [26]. The kinetics of nucleation and growth of these elements modeled by the TC-Prisma [23] module are illustrated in Figure 3.
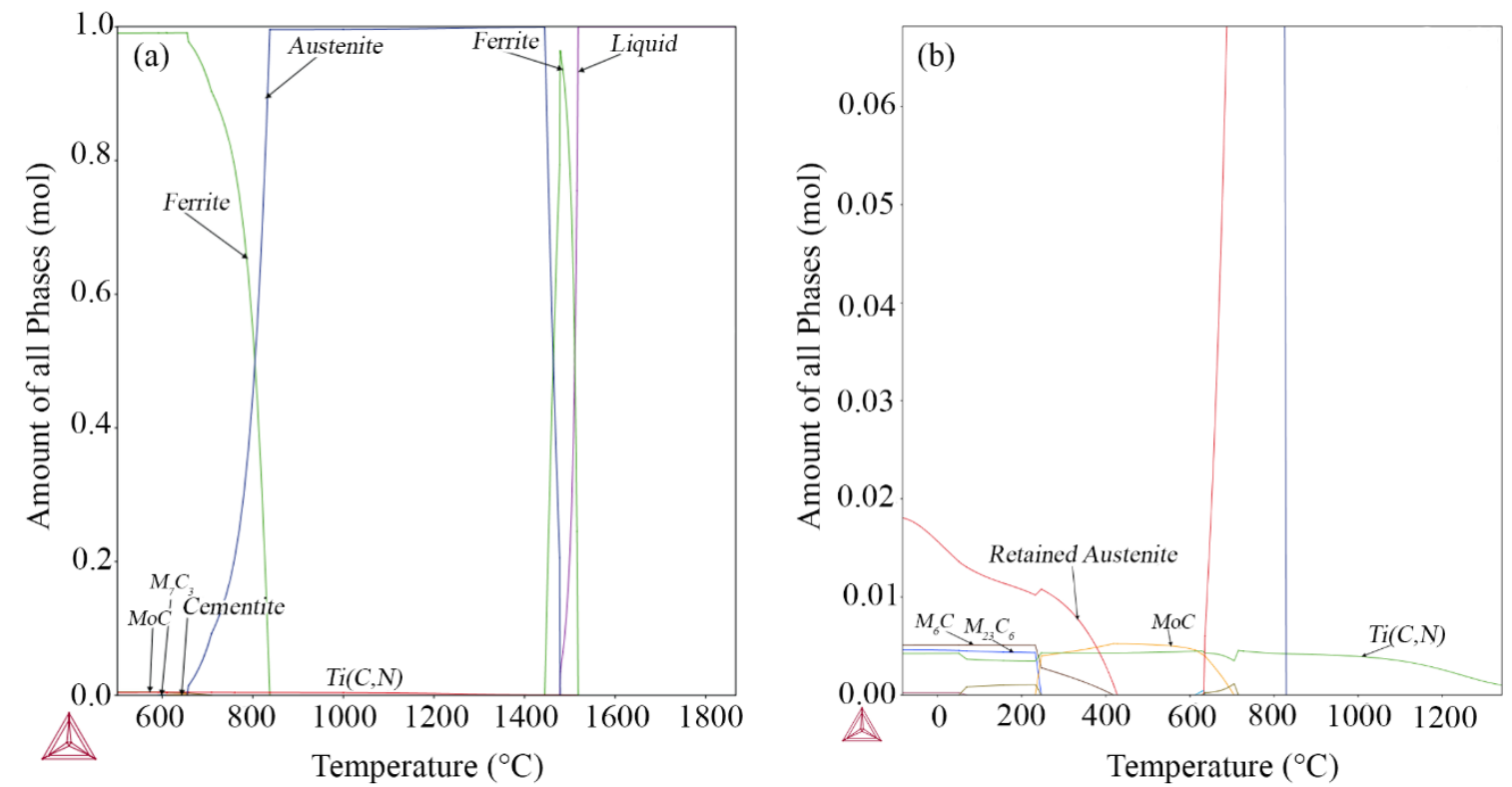

Figure 2. Amount of all phases calculated with Thermocalc: (a) full range of phases; (b) focus on carbides.
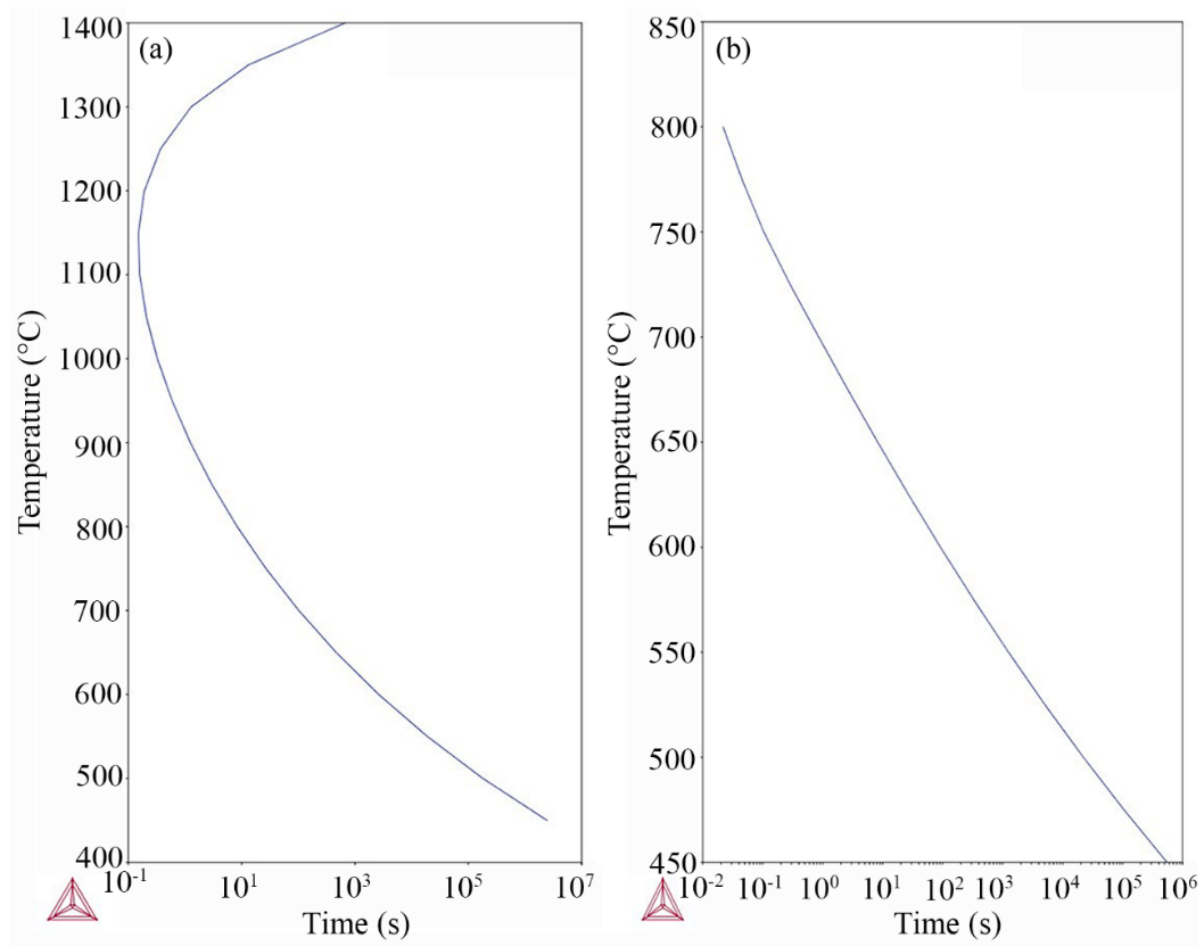

Figure 3. Time-temperature-precipitation (TTP) diagrams of (a) $\operatorname{Ti}(\mathrm{C}, \mathrm{N})$; (b) MoC. 
According to Figure $3 \mathrm{a}, \mathrm{Ti}(\mathrm{C}, \mathrm{N})$ nucleates at very high temperature, with a maximum rate at ca. $1150{ }^{\circ} \mathrm{C}$, at which it takes only $0.2 \mathrm{~s}$. At lower temperatures up to $800{ }^{\circ} \mathrm{C}$, the nucleation takes under $10 \mathrm{~s}$. The time for nucleation grows exponentially with decreasing temperature and nucleation takes a longer time than the longest partitioning time used in this work (maximum $50 \mathrm{~s}$ ). On the other hand, Figure $3 \mathrm{~b}$ shows that, although nucleation of this carbide $(\mathrm{MoC})$ is very fast, $600{ }^{\circ} \mathrm{C}$ is a critical temperature for this $\mathrm{Q} \& \mathrm{P}$, because below this temperature nucleation takes more than $100 \mathrm{~s}$, which means that nucleation of MoC cannot occur during this heat treatment. In summary, $\operatorname{Ti}(\mathrm{C}, \mathrm{N})$ precipitation could be an issue during welding and previous $\operatorname{Ti}(\mathrm{C}, \mathrm{N})$ particles from casting could still remain in the structure, but $\mathrm{MoC}$ precipitation occurs during the partitioning stage at $640{ }^{\circ} \mathrm{C}$.

\subsection{Carbon Partitioning}

Understanding the carbon movement during the partitioning stage at different temperatures with regard to the first quenched martensite and retained austenite grain boundaries has an important role in the prediction of the phase transformations. Comparison between the diffusion coefficient of carbon in austenite $\left(D_{\mathrm{c}}^{\gamma}\right)$ and ferrite $\left(D_{\mathrm{c}}{ }^{\alpha}\right)$ in Table 3 shows that for the temperature range of $\gamma+\alpha$ (440-640 ${ }^{\circ} \mathrm{C}$ in this case) the equilibrium ' $D$ ' is more than 100 times higher in ferrite than austenite. This means that carbon can partition out of martensite rapidly but will then pile up behind the $\alpha^{\prime} / \gamma$ grain boundary.

Table 3. Carbon diffusion coefficient in austenite $\left(D_{\mathrm{c}}^{\gamma}\right)$ and ferrite $\left(D_{\mathrm{c}}{ }^{\alpha}\right)$ and at different temperatures.

\begin{tabular}{cccc}
\hline Carbon Diffusion Coefficient & $\mathbf{4 4 0}{ }^{\circ} \mathbf{C}$ & $\mathbf{5 4 0}{ }^{\circ} \mathbf{C}$ & $\mathbf{6 4 0}^{\circ} \mathbf{C}$ \\
\hline$D_{\mathrm{c}}{ }^{\gamma}$ & $3.30 \times 10^{-16}$ & $7.12 \times 10^{-14}$ & $2.82 \times 10^{-21}$ \\
\hline$D_{\mathrm{C}}{ }^{\alpha}$ & $8.54 \times 10^{-13}$ & $4.49 \times 10^{-17}$ & $1.22 \times 10^{-18}$ \\
\hline
\end{tabular}

In other words, this velocity is critical for the determination of the area of retained austenite around tempered martensite plates, especially for low-carbon steels, in order to design the structural and mechanical properties of the material, since three different phenomena could occur during the partitioning stage: (i) The amount of austenite's carbon enrichment to stabilize it after the final quench; (ii) Nucleation and growth of third phases (e.g., bainitic ferrite); and (iii) Carbide precipitation. Nishikawa et al. [27] modeled the influence of the bainite reaction on the kinetics of carbon redistribution during the Q\&P process. Simulations indicate that the kinetics of carbon partitioning from martensite to austenite is controlled by carbon diffusion in austenite and is affected only to a small extent by the decomposition of austenite into bainitic ferrite.

Based on microscopy pictures of the samples, a model with $3 \mu \mathrm{m}$ space for austenite until the next lath of martensite and a $2 \mu \mathrm{m}$ space for ferrite, which represents martensite in this simulation, in a rectangular linear model with 50 nodes for calculations that are more frequent close to the interface, is assumed (see Figure 4).

Figure 5 shows the simulation results of carbon partitioning at $640{ }^{\circ} \mathrm{C}$ and $540{ }^{\circ} \mathrm{C}$. Regarding the fact that Mn drops the chemical potential of carbon in austenite, it is expected that regions with high Mn concentration attract more carbon [13]. Therefore, adding $1.78 \mathrm{wt} \% \mathrm{Mn}$ to the system makes carbon atoms pile up at the border of $\gamma / \alpha$ and causes a constant increase of the carbon content of austenite until $0.15 \mathrm{wt} \%$ after $50 \mathrm{~s}$ at $640{ }^{\circ} \mathrm{C}$. If the partitioning process stops after 2 or $5 \mathrm{~s}$, a small distance of approximately $0.5 \mu \mathrm{m}$ could be enriched with up to $0.3 \mathrm{wt} \% \mathrm{C}$ (Figure $5 \mathrm{a}$ ). As can be seen in Figure $5 \mathrm{~b}$, diffusion at $540{ }^{\circ} \mathrm{C}$ is much slower and makes the boundary full of carbon up to $1.6 \mathrm{wt} \%$. 

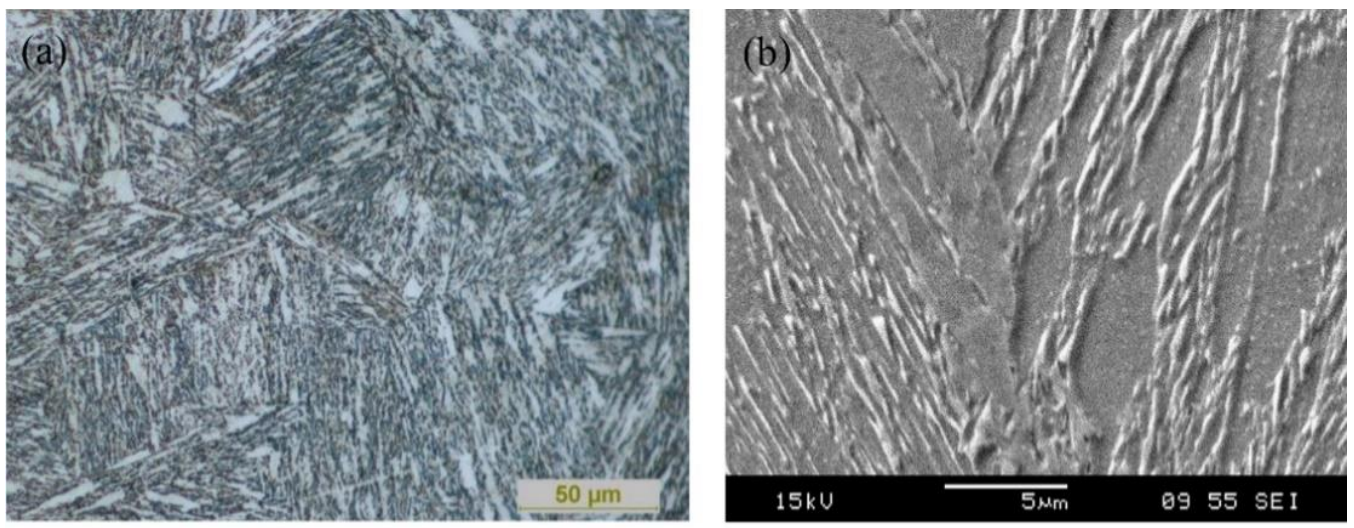

(c)

Austenite

Ferrite

$3 \mu \mathrm{m}$

$2 \mu \mathrm{m}$

Figure 4. (a) Optical microscopy (OM) and (b) SEM pictures of samples quenched to $350{ }^{\circ} \mathrm{C}$; (c) rectangular model with linear mesh assumed for $3 \mu \mathrm{m}$ austenite and $2 \mu \mathrm{m}$ martensite.
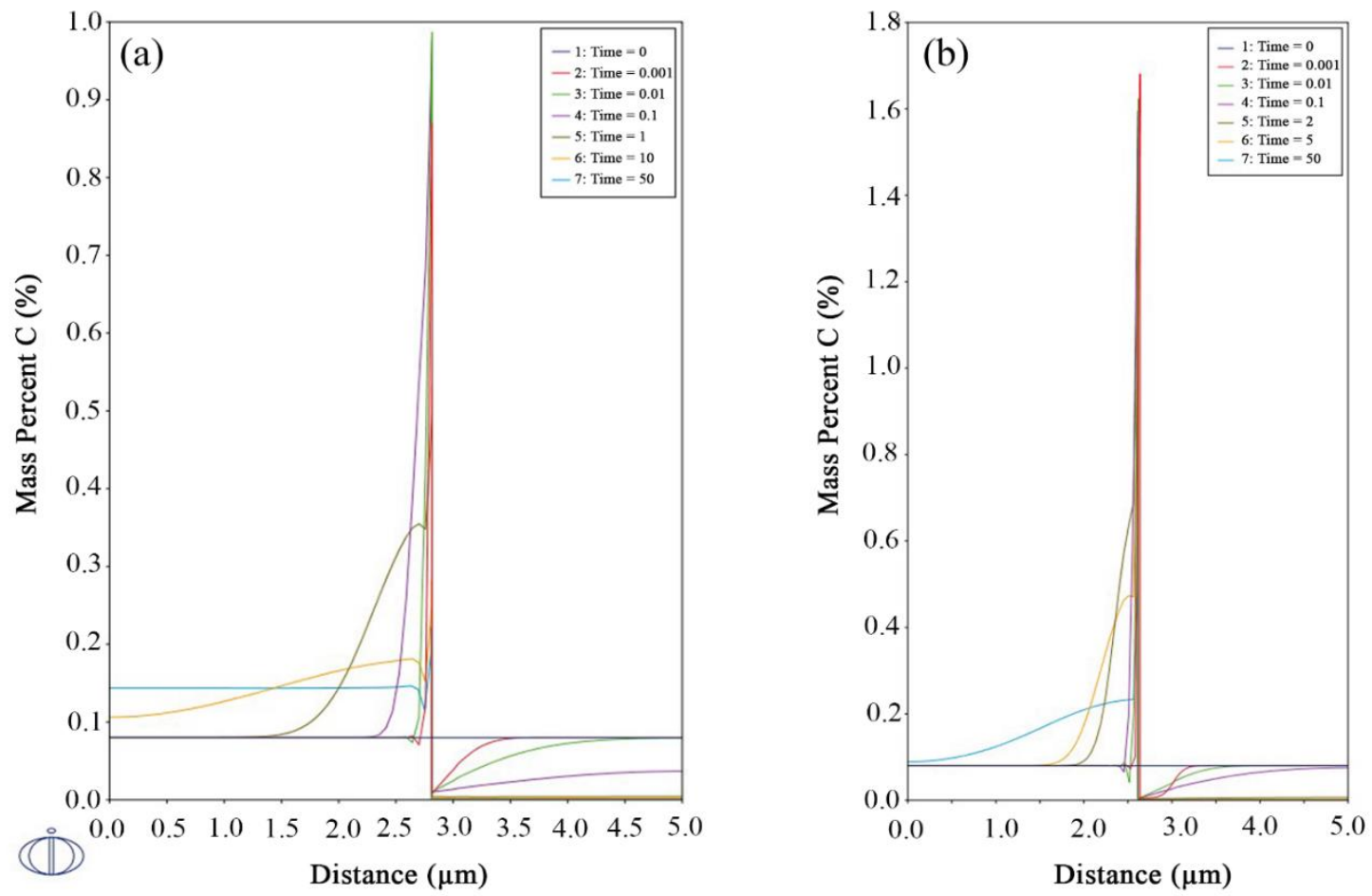

Figure 5. Carbon content of (a) Fe-0.08 wt \% C -1.78 wt $\%$ Mn system at $640{ }^{\circ} \mathrm{C}$; (b) Fe-0.08 wt \% C-1.78 wt $\%$ Mn system at $540{ }^{\circ} \mathrm{C}$.

In order to find the reason for the very low impact toughness results of samples partitioned at $640{ }^{\circ} \mathrm{C}$ while they have very good tensile properties, simulations were focused on $S(640,50)$ and $S(540,5)$ for comparison. The effect of temperature is shown in Figure 6a. Figure $6 \mathrm{~b}$ shows the carbon movement inside austenite close to the martensite interface for these two samples, and the existence of retained austenite after the final quench after partitioning can be predicted. 

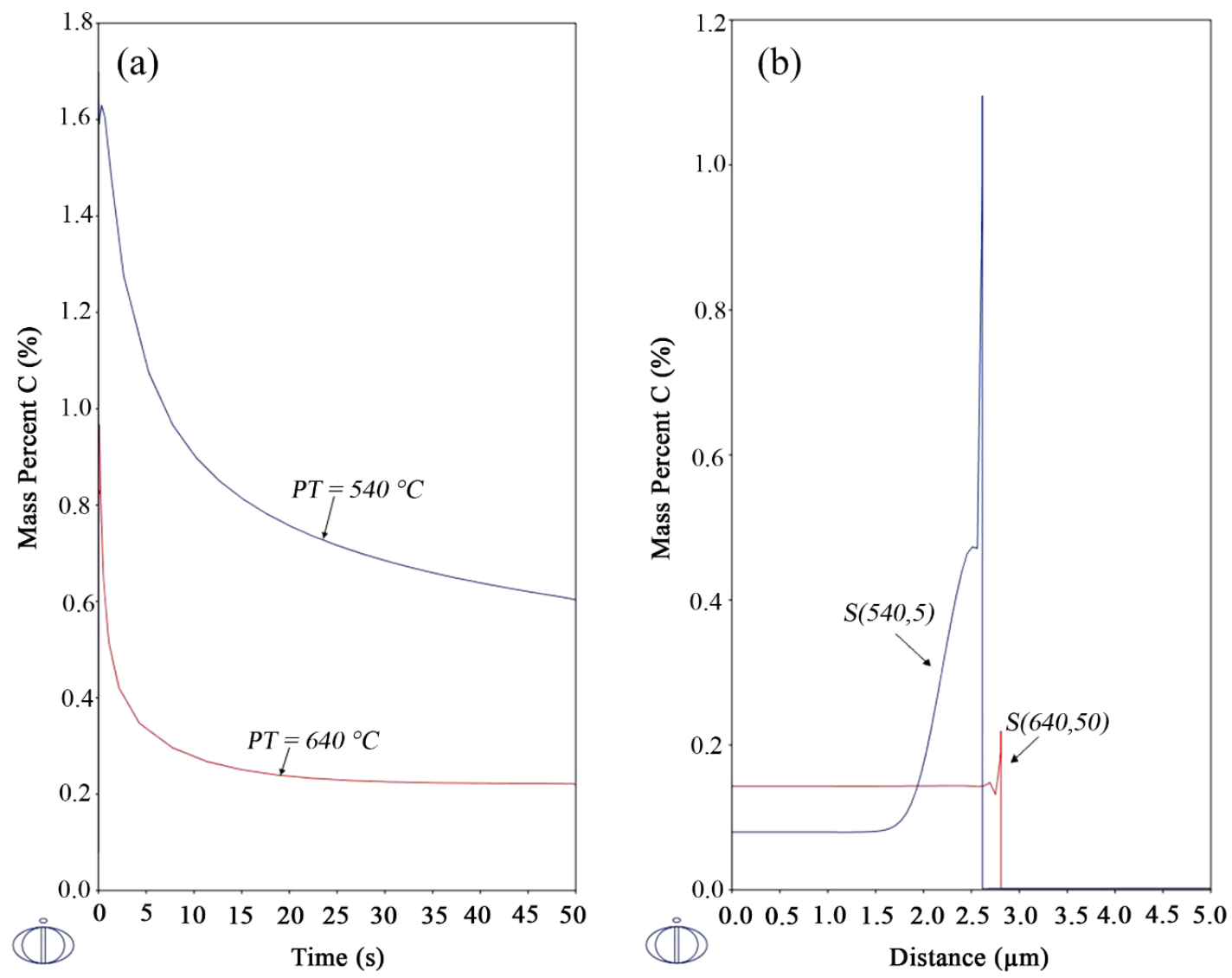

Figure 6. Comparison of samples partitioned at $540{ }^{\circ} \mathrm{C}, 5 \mathrm{~s}$ (blue) and $640{ }^{\circ} \mathrm{C}, 50 \mathrm{~s}$ (red), calculated using Dictra. (a) The composition of the interface as a function of the time; (b) carbon content vs. location $\gamma / \alpha$ interface is at $3 \mu \mathrm{m}$ distance).

Minimum estimated amount of $C$ to stabilize austenite, based on different equations [28-33] for this steel is 0.9 to $1.2 \mathrm{wt} \% \mathrm{C}$ at ambient temperature. So, comparing with Figure $6 \mathrm{~b}$ implies that there is no chance for stabilizing the retained austenite in $S(640,50)$, but there is some possibility in samples treated at $540{ }^{\circ} \mathrm{C}$ or less. This is also confirmed by XRD measurements of these two samples $\mathrm{S}(540,5)$ and $S(640,50)$.

Wu et al. [34] investigated the effect of austenite on fracture resistance of $Q \& P$ and showed that the energy absorption by transformation from austenite to martensite postponed the crack propagation and enhanced the fracture resistance of Q\&P steels. Even a small amount of retained austenite at room temperature could have a significant effect on energy absorption during crack propagation.

\subsection{Kinetics of Precipitation}

In Figure 3 it was shown that precipitation of $\mathrm{Ti}(\mathrm{C}, \mathrm{N})$ can start from the liquid. So, it is difficult to control the size and distribution of the $\operatorname{Ti}(\mathrm{C}, \mathrm{N})$ particles in the structure. However, SEM pictures of the Q\&P-treated sample shows small precipitates as well (Figure 7). EDS study of the particles confirmed the Ti content of these large and sharp-edged particles.

Beside these very large precipitates form during casting, there are some other particles that can nucleate, grow, or coarsen during welding and Q\&P treatment. For example, in Figure 7 different particle types can be seen in the HAZ. For example, in region (b) a $\operatorname{Ti}(\mathrm{C}, \mathrm{N})$ particle nucleated and coarsened during welding and Q\&P; region (c) shows accumulation of nucleated carbides at the grain boundary and (d) shows transition carbides that are created during tempering of martensite laths in the partitioning stage. 


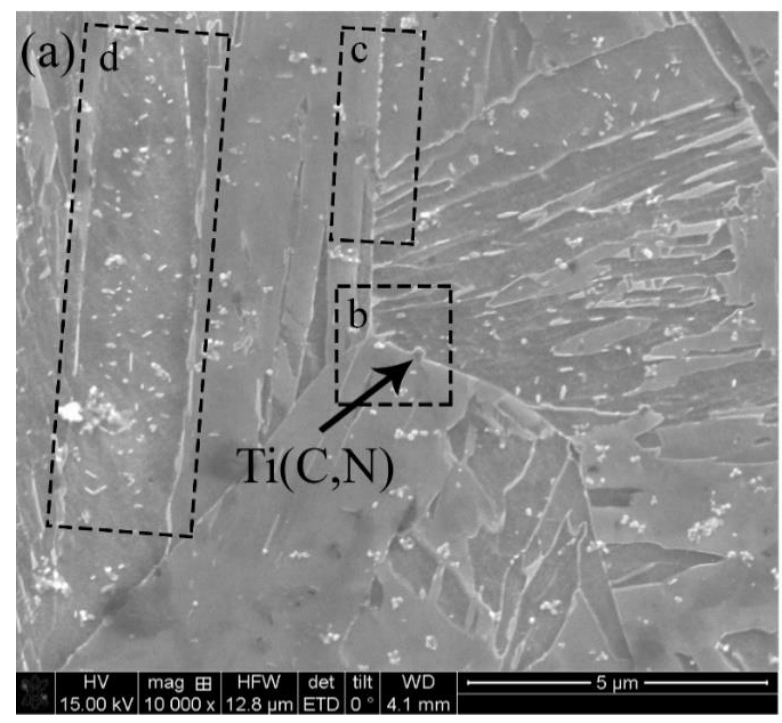

Figure 7. SEM pictures of $S(640,50)$ displays secondary precipitates at different size and shapes.

As reported by Gustafson [35], there are two sizes of TiC particles, one with sparsely distributed particles of micrometer size and a second with densely distributed particles with sizes of a few tens or hundreds of nanometers. In this work, precipitates with the smaller size were studied, under the assumption that the large primary particles are so sparsely distributed that they will not affect the coarsening of the secondary ones, since the coarsening of the large particles is expected to follow a much slower process and has no important influence on the mechanical properties.

Since the precipitates (especially the small ones) from casting will melt in FZ during welding, the most critical area will be HAZ. In order to model the nucleation and growth of precipitation using TC-Prisma, isothermal heating at $1350{ }^{\circ} \mathrm{C}$ for $5 \mathrm{~s}$ is considered. Figure 8 , shows that the equivalent average diameter of $\operatorname{Ti}(\mathrm{C}, \mathrm{N})$ particles is around $150 \mathrm{~nm}$.

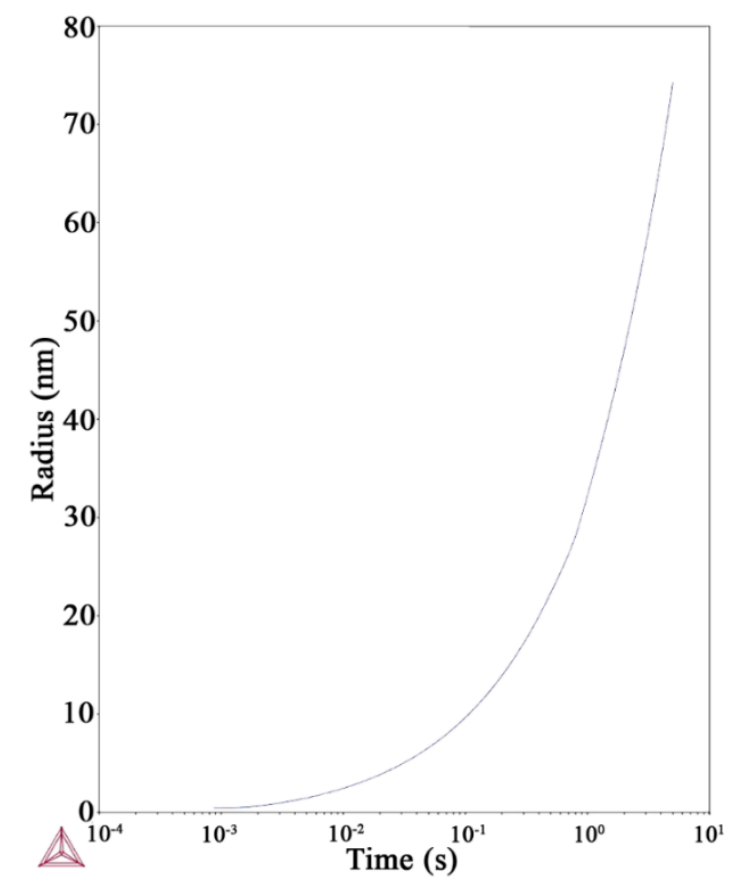

Figure 8. Prediction of precipitate size in $\mathrm{HAZ}$ considering isothermal heating at $1350{ }^{\circ} \mathrm{C}$ for $5 \mathrm{~s}$, resulting in a particle size of around $150 \mathrm{~nm}$. 
Comparison of the precipitate coarsening rates in corresponding matrix phases using the Thermocalc database shows that increasing the temperature from $540{ }^{\circ} \mathrm{C}$ to $640{ }^{\circ} \mathrm{C}$ will increase the coarsening rate of $\operatorname{Ti}(\mathrm{C}, \mathrm{N}) 1000$ times to $1.27 \times 10^{-35} \mathrm{~m}^{3} / \mathrm{s}$ and of $\mathrm{MoC} 100$ times to $3.875 \times 10^{-31} \mathrm{~m}^{3} / \mathrm{s}$.

Quantification of the precipitate size distribution in base material (BM) and in those partitioned at $540{ }^{\circ} \mathrm{C}$ and $640{ }^{\circ} \mathrm{C}$ was carried out by STEM from carbon replicas of the samples.

Figure 9 shows the particle size distribution for both partitioned samples (at $540{ }^{\circ} \mathrm{C}$ and $640{ }^{\circ} \mathrm{C}$ ) and for the BM. The average particle size was calculated to be $0.263 \pm 0.108 \mu \mathrm{m}, 0.207 \pm 0.089 \mu \mathrm{m}$, and $0.07 \pm 0.11 \mu \mathrm{m}$ for $S(540,5), S(640,50)$, and $B M$, respectively. The precipitates quantification in the BM became more complicated since it presents particles over a large range of sizes. SEM analysis of precipitates show a few large particles (between 0.2 and $0.65 \mu \mathrm{m}$ ) at relatively low magnification $(20,000 \times)$. However, at higher magnifications (e.g., 80,000×), a large quantity of small particles $(<0.2 \mu \mathrm{m})$ can be distinguished. For this reason, the analysis of the precipitates in this sample was performed at two different magnifications.
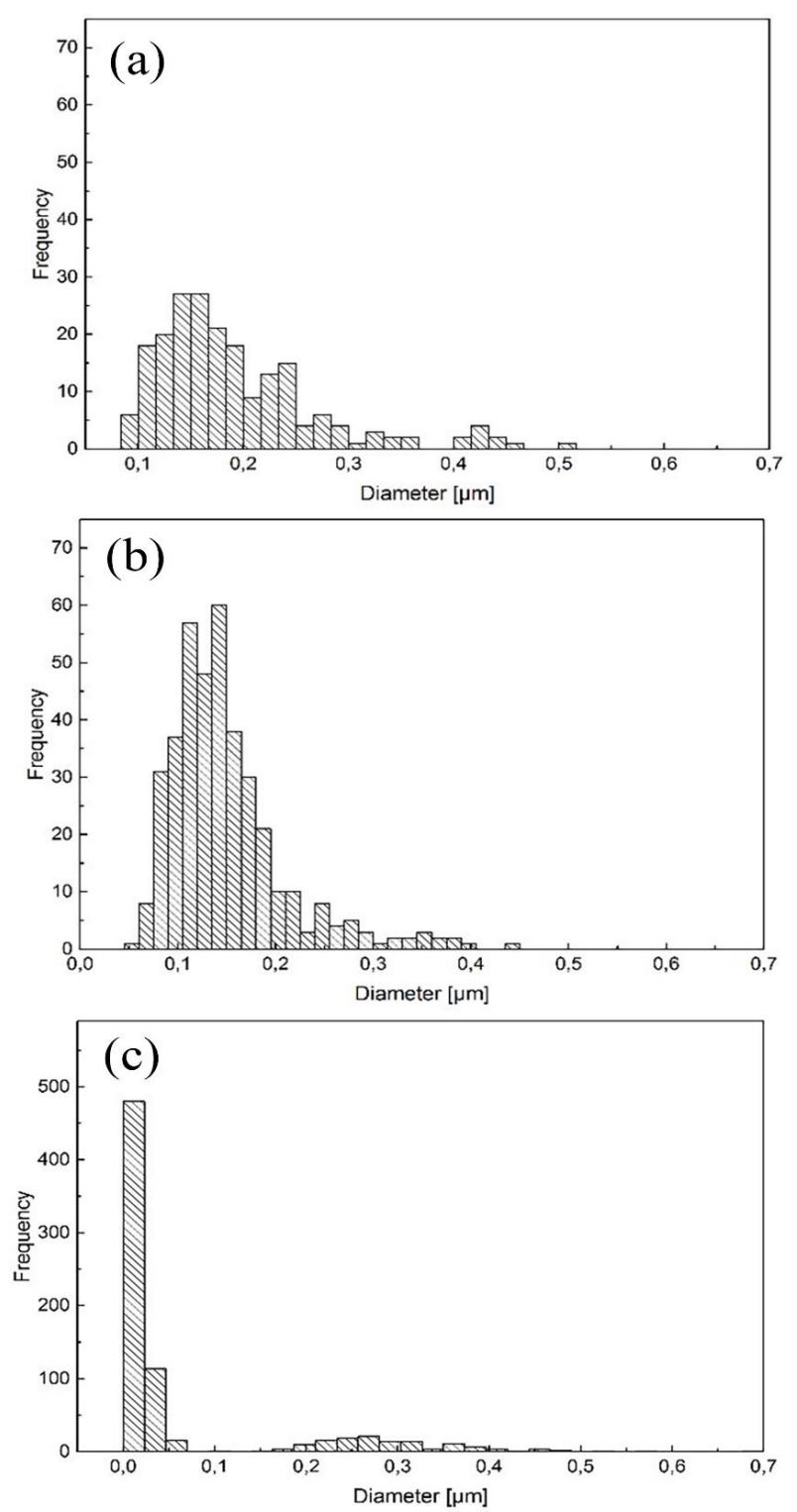

Figure 9. Measured size distribution of precipitates vs. number of particles for post-welding heat-treated samples (a) at QT $=355{ }^{\circ} \mathrm{C}$ and PT $=540{ }^{\circ} \mathrm{C}$ for $5 \mathrm{~s}$; (b) at QT $=355{ }^{\circ} \mathrm{C}$ and $\mathrm{PT}=$ $640{ }^{\circ} \mathrm{C}$ for $50 \mathrm{~s}$; (c) base metal. 
Figure 10 shows STEM images from $C$ replicas corresponding to the samples. An apparently larger particle density can be observed in the sample partitioned at $640{ }^{\circ} \mathrm{C}$, when comparing the same area of both samples (Figure 10a,b). However, the particle density has not been systematically analyzed in this case. Two hundred six and 388 particles were considered for $S(540,5)$ and $S(640,50)$, respectively, and this was compared with the base metal (see Figure 9).

Results indicate that the approximate average size of particles in treated samples are $0.263 \pm 0.108 \mu \mathrm{m}$ for the sample partitioned at $540{ }^{\circ} \mathrm{C}$ and $0.207 \pm 0.089 \mu \mathrm{m}$ for the one partitioned at $640{ }^{\circ} \mathrm{C}$, while the number density of particles after partitioning at $640{ }^{\circ} \mathrm{C}$ is around 1.5 times higher than for $540{ }^{\circ} \mathrm{C}$. This can be seen when comparing Figure 10a,b.
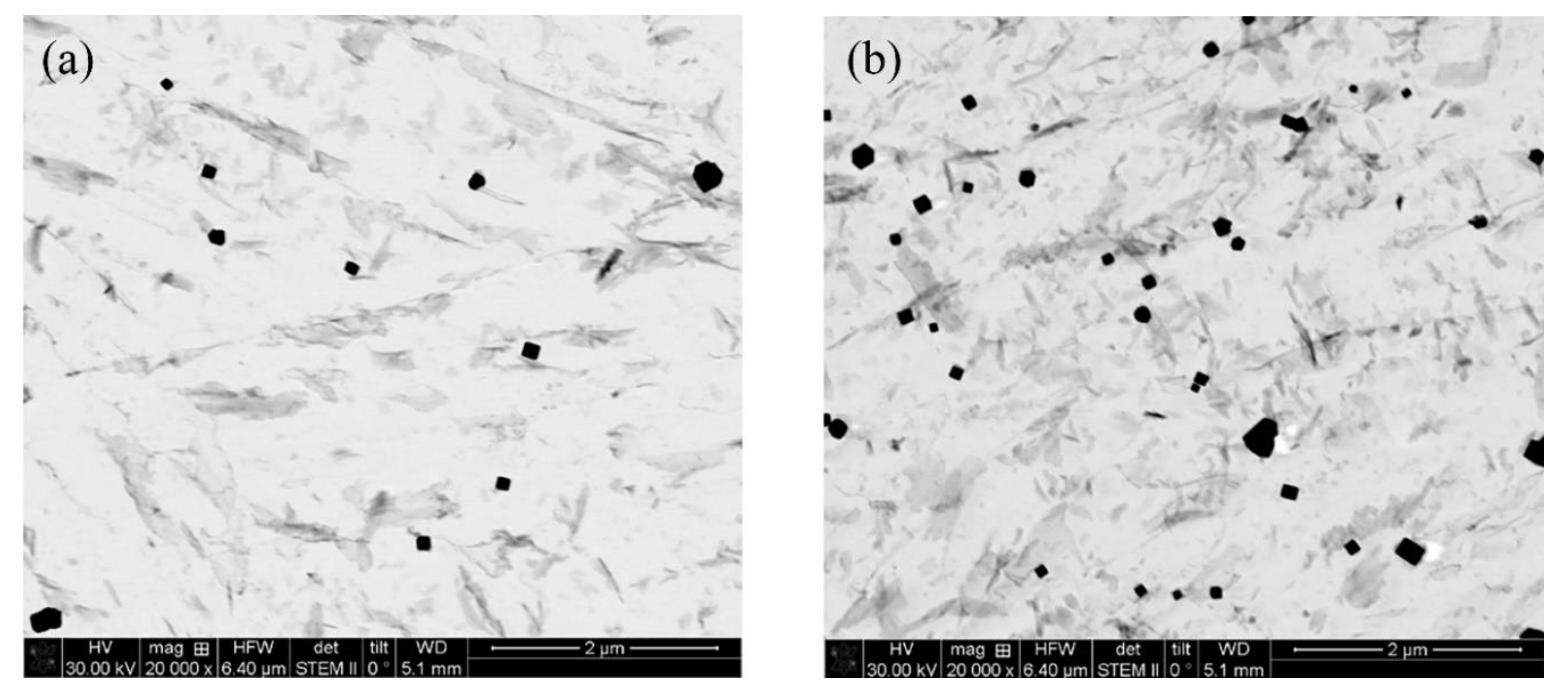

Figure 10. Comparison between distribution, number density, and shape of the particles in carbon replicas made from the sample: (a) $S(540,5)$ and (b) $S(640,50)$.

From EDS measurements, it was determined that the particles in samples partitioned at $540{ }^{\circ} \mathrm{C}$ and $640{ }^{\circ} \mathrm{C}$ are principally MoC (round shaped particles) and $\mathrm{Ti}(\mathrm{C}, \mathrm{N})$ (rectangular shaped particles).

\subsection{Grain Size Effect}

As mentioned before, the structure is made of tempered and fresh martensite lathes from the first and second quench and bainite from the partitioning stage. So, the toughness of such structure is increased by a high density of the high angle boundaries created, because this kind of boundary acts as an obstacle for cleavage propagation, forcing the cleavage crack to change its microscopic plane of propagation in order to accommodate the new local crystallography [22,36,37]. In addition, the presence of coarse martensite laths leads to early strain localization, especially when they are in the vicinity of untempered martensite islands [38]. However, the complexity of the lath martensitic/bainitic structure makes the grain size measurement very difficult. For this reason, the region of martensite/bainite lathes with a determined crystallographic orientation is defined as a block [39]. Clusters of blocks form a packet when they share the same (111) $)_{\gamma}$, to which the corresponding $(001)_{\alpha}$ is almost parallel [40]. Since the blocks and packages present high angle grain boundaries $\left(>11^{\circ}\right)$, the toughness of the material might be influenced by their size [41]. In this study, the effective grain size of the martensite/bainite was determined from EBSD measurements, considering grain boundary misorientation $\geq 15^{\circ}$. Figure 11 shows the inverse pole figure (IPF) superimposed on the image quality map (IQ) for the treated samples. Results shows that partitioning at a lower temperature $\left(540^{\circ} \mathrm{C}\right)$ leads to a refinement of the effective grain size (block packages), as can be noticed by the change in the color orientation. Kawata et al. [42] showed that the bainite block is coarsened by ausforming, especially for a higher temperature, by formation of preferred variants in a packet. In contrast, the same ausforming treatments refine the lath martensite block. In fact, packet size will 
influence the ductile-brittle transition temperature (DBTT). As mentioned in Equation (1), DBTT (T) is inversely proportional to the root square of the distance between high-angle grain boundaries $(d)$, where $\mathrm{K}$ is a constant [36]:

$$
T=T_{0}-K^{-2}
$$
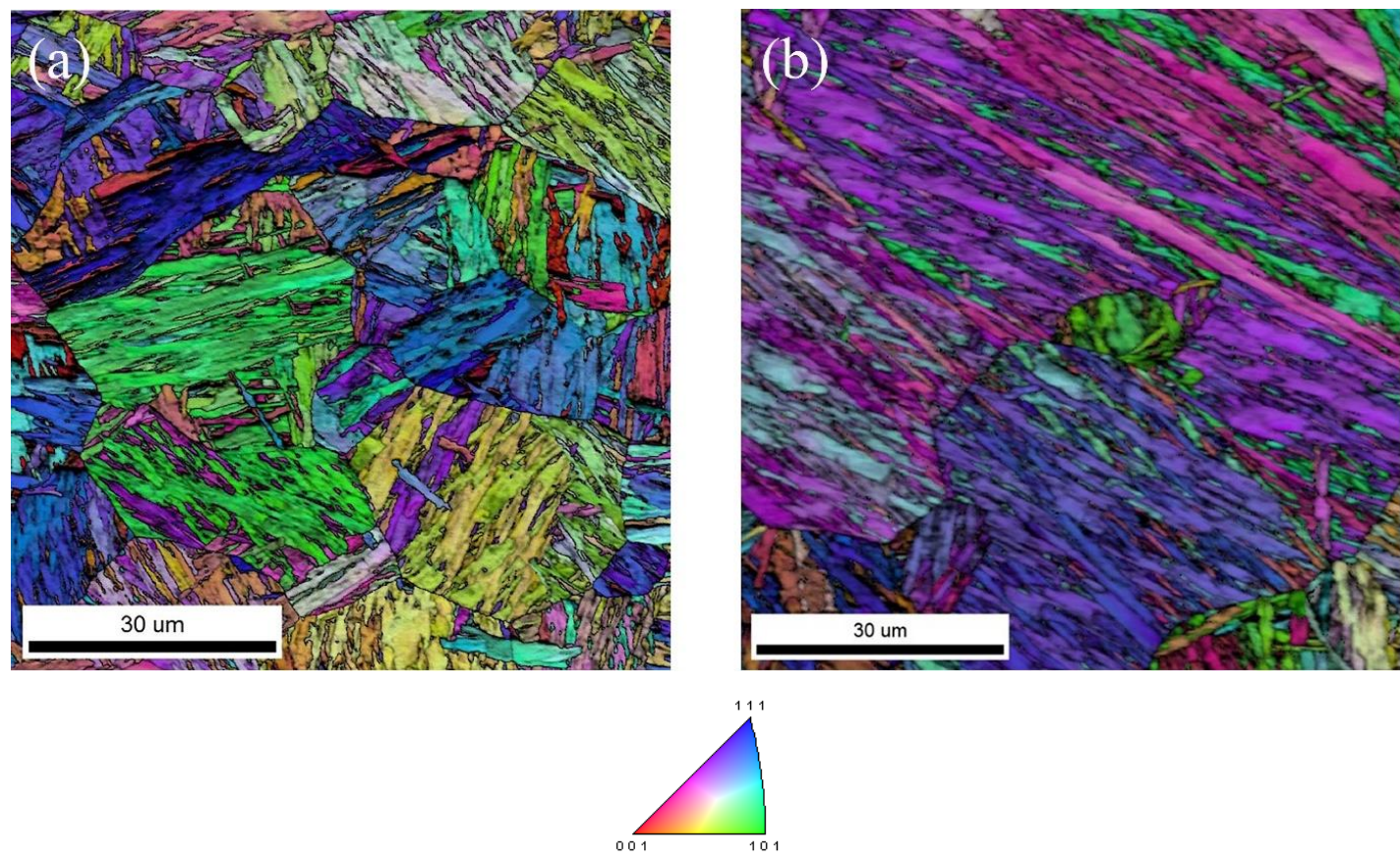

Figure 11. IPF + IQ picture from EBSD analysis of samples: (a) $S(540,5)$; (b) $S(640,50)$.

\section{Conclusions}

The aim of this work was to investigate the reason for brittle fracture of the samples from a low-carbon, low-Si AHSS, which were post-weld heat-treated by the Q\&P method around $B_{s}$ temperature $\left(640^{\circ} \mathrm{C}\right)$. Their strength and ductility were the best in comparison with other samples partitioned at lower temperatures, i.e., $540{ }^{\circ} \mathrm{C}$ and $440{ }^{\circ} \mathrm{C}$. Results shows that since $\mathrm{D}_{\mathrm{c}} \alpha^{\prime}$ is much higher than $\mathrm{D}_{\mathrm{c}}^{\gamma}$ carbon diffuses out from martensite and piles up behind the border of $\alpha^{\prime} / \gamma$. The partitioning temperature controls the rate of carbon diffusion, but this amount at the $\alpha^{\prime} / \gamma$ border cannot reach the level necessary to stabilize austenite at $640{ }^{\circ} \mathrm{C}$, while it can occur for a small area next to the border at $540{ }^{\circ} \mathrm{C}$. Subsequently, this RA can contribute to eliminating the brittle fracture due to the TRIP effect and increasing the impact toughness.

STEM results of carbon replicas revealed that there are many more very small precipitates $(<0.1 \mu \mathrm{m})$ in the sample partitioned at $640{ }^{\circ} \mathrm{C}$; this can increase the strength of the material via precipitation strengthening mechanism. On the other hand, EBSD results showed much larger crystallographic packets in this sample, which can result in a lowering of the material strength. The increase of strength by precipitation strengthening and the decrease of the strength due to larger packet size will counteract each other so that the tensile test results of the samples partitioned at $640{ }^{\circ} \mathrm{C}$ are still good.

Author Contributions: Concept and design of experiments: F.F. and E.V.; Experiments, simulations, analysis of data and writing the original draft: F.F.; Experiments and revising the paper: M.A.G.; Supervision: E.V. and F.M.

Funding: This research was funded by Erasmus+: Erasmus Mundus Joint Doctorate (EMJD)-Advanced Materials Engineering-DOCMASE, grant number "2011-0020".

Acknowledgments: The support of the EUSMAT (European School of Materials) via the Ph.D. program 'DOCMASE' and Flavio Soldera is gratefully acknowledged by the authors.

Conflicts of Interest: The authors declare no conflict of interest. 


\section{References}

1. Opbroek, E. UltraLight Steel: A Global Consortium Changes the Future of Automotive Steel; Xlibris: Bloomington, IN, USA, 2013; ISBN 1479773441.

2. Shome, M.; Tumuluru, M. Welding and Joining of Advanced High Strength Steels (AHSS), 1st ed.; Woodhead Publishing: Cambridge, UK, 2015; ISBN 9780857098580.

3. Speer, J.; Matlock, D.K.; De Cooman, B.C.; Schroth, J.G. Carbon partitioning into austenite after martensite transformation. Acta Mater. 2003, 51, 2611-2622. [CrossRef]

4. Forouzan, F.; Vuorinen, E.; Mücklich, F. Post weld-treatment of laser welded AHSS by application of quenching and partitioning technique. Mater. Sci. Eng. A 2017, 698, 174-182. [CrossRef]

5. Clarke, A.J.; Speer, J.G.; Miller, M.K.; Hackenberg, R.E.; Edmonds, D.V.; Matlock, D.K.; Rizzo, F.C.; Clarke, K.D.; De Moor, E. Carbon partitioning to austenite from martensite or bainite during the quench and partition (Q\&P) process: A critical assessment. Acta Mater. 2008, 56, 16-22. [CrossRef]

6. Santofimia, M.J.; Zhao, L.; Sietsma, J. Microstructural Evolution of a Low-Carbon Steel during Application of Quenching and Partitioning Heat Treatments after Partial Austenitization. Metall. Mater. Trans. A 2009, 40, 46-57. [CrossRef]

7. Toji, Y.; Miyamoto, G.; Raabe, D. Carbon partitioning during quenching and partitioning heat treatment accompanied by carbide precipitation. Acta Mater. 2015, 86, 137-147. [CrossRef]

8. Charleux, M.; Poole, W.J.; Militzer, M.; Deschamps, A. Precipitation behavior and its effect on strengthening of an HSLA-Nb/Ti steel. Metall. Mater. Trans. A 2001, 32, 1635-1647. [CrossRef]

9. Soto, R.; Saikaly, W.; Bano, X.; Issartel, C.; Rigaut, G.; Charai, A. Statistical and theoretical analysis of precipitates in dual-phase steels microalloyed with titanium and their effect on mechanical properties. Acta Mater. 1999, 47, 3475-3481. [CrossRef]

10. Toji, Y.; Matsuda, H.; Herbig, M.; Choi, P.; Raabe, D. Atomic-scale analysis of carbon partitioning between martensite and austenite by atom probe tomography and correlative transmission electron microscopy. Acta Mater. 2014, 65, 215-228. [CrossRef]

11. Fairchild, D.P.; Howden, D.G.; Clark, W.A.T. The mechanism of brittle fracture in a microalloyed steel: Part I. Inclusion-induced cleavage. Metall. Mater. Trans. A 2000, 31, 641-652. [CrossRef]

12. Di Schino, A.; Di Nunzio, P.E. Effect of $\mathrm{Nb}$ microalloying on the heat affected zone microstructure of girth welded joints. Mater. Lett. 2017, 186, 86-89. [CrossRef]

13. HajyAkbary, F.; Sietsma, J.; Miyamoto, G.; Furuhara, T.; Santofimia, M.J. Interaction of carbon partitioning, carbide precipitation and bainite formation during the Q\&P process in a low $C$ steel. Acta Mater. 2016, 104, 72-83. [CrossRef]

14. Clarke, A.J.; Speer, J.G.; Matlock, D.K.; Rizzo, F.C.; Edmonds, D.V.; Santofimia, M.J. Influence of carbon partitioning kinetics on final austenite fraction during quenching and partitioning. Scr. Mater. 2009, 61, 149-152. [CrossRef]

15. Somani, M.C.; Porter, D.A.; Karjalainen, L.P.; Misra, R.D.K. On Various Aspects of Decomposition of Austenite in a High-Silicon Steel During Quenching and Partitioning. Metall. Mater. Trans. A 2014, 45, 1247-1257. [CrossRef]

16. Santofimia, M.J.; Zhao, L.; Sietsma, J. Overview of Mechanisms Involved During the Quenching and Partitioning Process in Steels. Metall. Mater. Trans. A 2011, 42, 3620-3626. [CrossRef]

17. Thomas, G.A.; Speer, J.G. Interface migration during partitioning of Q\&P Steel. Mater. Sci. Technol. 2014, 30, 998-1007. [CrossRef]

18. De Knijf, D.; Petrov, R.; Föjer, C.; Kestens, L.A. Effect of fresh martensite on the stability of retained austenite in quenching and partitioning steel. Mater. Sci. Eng. A 2014, 615, 107-115. [CrossRef]

19. De Knijf, D.; Puype, A.; Föjer, C.; Petrov, R. The influence of ultra-fast annealing prior to quenching and partitioning on the microstructure and mechanical properties. Mater. Sci. Eng. A 2015, 627, 182-190. [CrossRef]

20. De Diego-Calderón, I.; Sabirov, I.; Molina-Aldareguia, J.M.; Föjer, C.; Thiessen, R.; Petrov, R.H. Microstructural design in quenched and partitioned (Q\&P) steels to improve their fracture properties. Mater. Sci. Eng. A 2016, 657, 136-146. [CrossRef]

21. Wang, C.; Wang, M.; Shi, J.; Hui, W.; Dong, H. Effect of microstructural refinement on the toughness of low carbon martensitic steel. Scr. Mater. 2008, 58, 492-495. [CrossRef] 
22. Forouzan, F.; Gunasekaran, S.; Hedayati, A.; Vuorinen, E.; Mucklich, F. Microstructure analysis and mechanical properties of Low alloy High strength Quenched and Partitioned Steel. DiVA 2016, 258, 574-578. [CrossRef]

23. Andersson, J.O.; Helander, T.; Höglund, L.; Shi, P.F.; Sundman, B. Thermo-Calc \& DICTRA, Computational tools for materials science. Calphad 2002, 26, 273-312.

24. Thermo-Calc Software TCFE9 Steels/Fe-alloys Database. Available online: https://www.thermocalc.com/ products-services/databases/thermodynamic/ (accessed on 20 September 2018).

25. A.B. MOBFE3: TCS Steels/Fe-Alloys Mobility Database. Thermo-Calc Software. Available online: https: / / www.thermocalc.com/products-services/databases/mobility/ (accessed on 20 September 2018).

26. Bhadeshia, H.; Honeycombe, R. Microstructure and properties. In Steels: Microstructure and Properties, 3rd ed.; Butterworth-Heinemann: Cambridge, UK, 2011; ISBN 0080462928, 9780080462929.

27. Nishikawa, A.S.; Santofimia, M.J.; Sietsma, J.; Goldenstein, H. Influence of bainite reaction on the kinetics of carbon redistribution during the Quenching and Partitioning process. Acta Mater. 2018, 142, 142-151. [CrossRef]

28. Payson, P.; Savage, C.H. Martensite reactions in alloy steels. Trans. ASM 1944, 33, 261-280.

29. Grange, R.A.; Stewart, H.M. The temperature range of martensite formation. Trans. AIME 1946, 167, 467-501.

30. Van Bohemen, S. Bainite and martensite start temperature calculated with exponential carbon dependence. Mater. Sci. Technol. 2012, 28, 487-495. [CrossRef]

31. Nehrenberg, A.E. Contribution to Discussion on Grange and Stewart. Trans. Am. Inst. Min. Met. Eng. 1946, 167, 494-498.

32. Haynes, A.G.; Steven, W. The temperature of formation of martensite and bainite in low-alloy steel. J. Iron Steel Inst. 1956, 183, 349-359.

33. Andrews, K.W. Empirical formulae for the calculation of some transformation temperatures. J. Iron Steel Inst. 1965, 203, 721-727.

34. Wu, R.; Li, J.; Li, W.; Wu, X.; Jin, X.; Zhou, S.; Wang, L. Effect of metastable austenite on fracture resistance of quenched and partitioned (Q\&P) sheet steels. Mater. Sci. Eng. A 2016, 657, 57-63. [CrossRef]

35. Gustafson, $\AA$. Coarsening of $\mathrm{TiC}$ in austenitic stainless steel-experiments and simulations in comparison. Mater. Sci. Eng. A 2000, 287, 52-58. [CrossRef]

36. Díaz-Fuentes, M.; Iza-Mendia, A.; Gutiérrez, I. Analysis of different acicular ferrite microstructures in low-carbon steels by electron backscattered diffraction. Study of their toughness behavior. Metall. Mater. Trans. A 2003, 34, 2505-2516. [CrossRef]

37. Rodriguez-Ibabe, J. The Role of Microstructure in Toughness Behaviour of Microalloyed Steels. Mater. Sci. Forum. 1998, 284-286, 51-62. [CrossRef]

38. Wang, M.; Hell, J.; Tasan, C.C. Martensite size effects on damage in quenching and partitioning steels. Scr. Mater. 2017, 138, 1-5. [CrossRef]

39. Verbeken, K.; Barbé, L.; Raabe, D. Evaluation of the crystallographic orientation relationships between FCC and BCC phases in TRIP steels. ISIJ Int. 2009, 49, 1601-1609. [CrossRef]

40. Morito, S.; Tanaka, H.; Konishi, R.; Furuhara, T.; Maki, T. The morphology and crystallography of lath martensite in Fe-C alloys. Acta Mater. 2003, 51, 1789-1799. [CrossRef]

41. Bhadeshia, H.K.D.H. Bainite in Steels. In Theory and Practice, 3rd ed.; Maney Publishing: Cambridge, UK, 2015; ISBN 1909662747, 9781909662742.

42. Kawata, H.; Sakamoto, K.; Moritani, T.; Morito, S.; Furuhara, T.; Maki, T. Crystallography of ausformed upper bainite structure in Fe-9Ni-C alloys. Mater. Sci. Eng. A 2006, 438, 140-144. [CrossRef]

(C) 2018 by the authors. Licensee MDPI, Basel, Switzerland. This article is an open access article distributed under the terms and conditions of the Creative Commons Attribution (CC BY) license (http://creativecommons.org/licenses/by/4.0/). 